Jeremy W. Barrier

\title{
The Acts of Paul and Thecla
}

\section{A Critical Introduction and Commentary}

[Die Taten des Paulus und der Thekla. Kritische Einführung und Kommentar.]

Veröffentlicht auf Englisch.

Jeremy W. Barrier übersetzt und kommentiert im vorliegenden Band die Taten des Paulus und der Thekla, einen seit dem zweiten Jahrhundert bekannten frühchristlichen Text. Das Buch enthält neben dem griechischen Text samt englischer Übersetzung und Kommentaren eine ausführliche kritische Einleitung.

The Acts of

Paul and Thecla

Jeremy W. Barrier Born 1979; BA in Mathematics and Natural Science; MA in New Testament from Freed-Hardeman University; 2008 PhD from Brite Divinity School, Texas Christian University; Assistant Professor in Biblical Literature at Heritage Christian University, Florence, AL.

\section{Jetzt bestellen:}

https://mohrsiebeck.com/buch/the-acts-of-paul-and-thecla-9783161516139?no_cache=1

order@mohrsiebeck.com

Telefon: +49 (0)7071-923-17

Telefax: +49 (0)7071-51104 